\title{
Overview of Piano Key weir prototypes and scientific model investigations
}

\author{
Marcelo Leite Ribeiro \\ Stucky Ltd., Rue du Lac 33, CH - 1020 Renens, Switzerland \\ Michael Pfister and Anton J. Schleiss \\ Laboratory of Hydraulic Constructions (LCH), Ecole Polytechnique Fédérale de Lausanne (EPFL), \\ Station 18, CH - 1015 Lausanne, Switzerland
}

\begin{abstract}
The interest in Piano Key weirs (PKW) was increasing over the past years, both in terms of application and hydraulic research. Several systematic model test series were performed and published so far, originating from different hydraulic laboratories around the world. Therein, the key geometric parameters dominating the hydraulic capacity of PKWs were identified as developed crest length, transversal weir width, height of the walls and key widths. The present paper compares the available data-sets provided by several laboratories and as constructed on prototypes, partially including a systematic model testing of the relevant parameters. The present overview is based on the geometrical dimensions of the investigated and designed PKWs, without giving any hydraulic examination.
\end{abstract}

\section{INTRODUCTION}

Piano Key weirs, representing an alternative to the traditional Labyrinth weirs, are used as efficient spillway inlet on dam rehabilitation projects (Leite Ribeiro et al. 2007, Laugier et al. 2009, Pinchard et al., 2011, Erpicum et al. 2011), as well as for new dam projects (Lempérière et al. 2011, Ho Ta Khanh 2011a). In addition to the increase in discharge capacity as compared to traditional Labyrinth weirs (Blancher et al. 2011, Anderson and Tullis 2011, 2012), PKWs have typically techno-economic advantages as: (i) minor impact on dam structure; (ii) minor or negligible impact on existing gates and other components, (iii) reliability of free surface overflow inlets, requiring little maintenance, (iv) low cost solution involving the construction of repeating concrete units (Lempériere and Ouamane, 2003; Laugier, 2007; Leite Ribeiro et al, 2009, Vermeulen et al; 2011), and (v) small sensitivity to debris accumulation (Pfister et al. 2013).

Compared to a linear weir, the efficiency of a PKW is mainly a consequence of its longer developed crest. However, with increasing upstream head, this advantage gets lost (Leite Ribeiro et al. 2012a, c, Machiels et al. 2011b, Ouamane and Lempérière 2006). As a consequence, PKWs are typically designed to operate under relative moderate heads, nevertheless resulting in a significant discharge capacity.

Given that many prototypes were erected in the past years, mainly designed using physical model studies, and as a consequence of several systematic research studies, including physical and numerical modeling, extensive hydraulic data related to hydraulic features of PKWs are today available. These contribute to the increase of comprehension regarding to the hydraulic behavior of PKWs. Nowadays, the key geometrical parameters influencing the hydraulic capacity of a PKW, namely the developed crest length, $L$, the transversal width $W$, the width of the inlet and outlet keys $W_{i}$ and $W_{o}$, and the height of the inlet key $P_{i}$, were determined (Figure 1). 
The discharge capacity of a PKW is affected influenced by further geometrical parameters, as the upstream approach flow channel conditions, the height and position of eventual parapet walls $P_{p x}$, the crest shape, the shape of the upstream diffuser, the height of the foundation $P_{d}$, the up- and downstream overhang lengths $B_{o}$ and $B_{i}$, and the tailwater conditions. However, the influence of these parameters can be considered as secondary in comparison with the influence of the key parameters as described above. Some attention has been recently directed to the thickness of the walls (Laugier et al. 2011). As PKWs typically operate under low heads, low values of the ratio $H / T_{s}$ can decrease the discharge coefficient of the walls, then operating as broad-crested weirs instead of sharp-crested weirs.
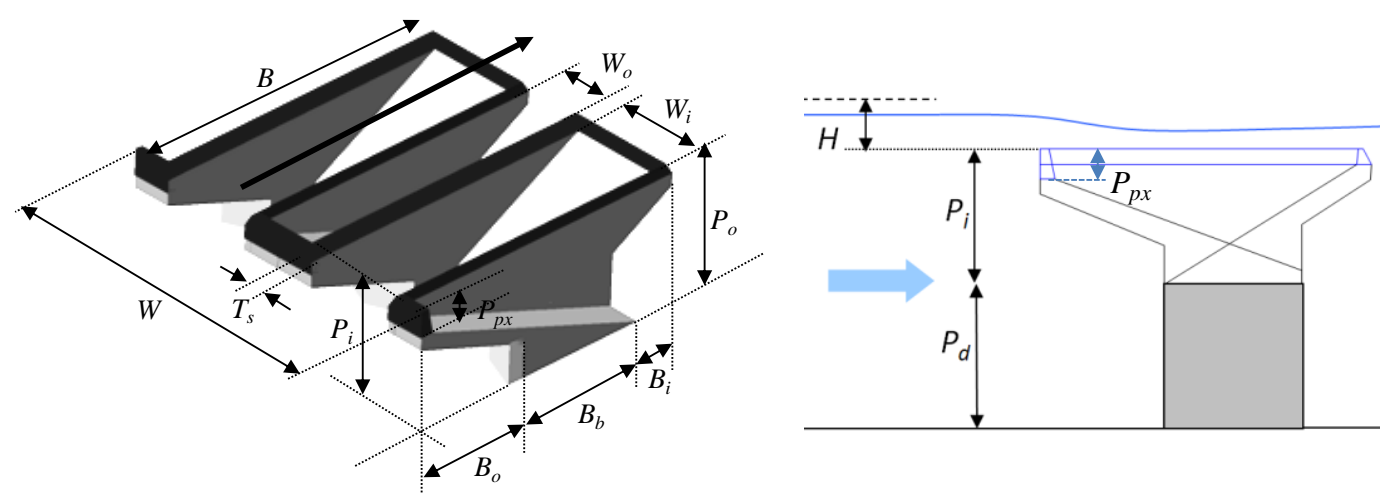

Figure 1. PKW Nomenclature according to Pralong et al. (2011).

The present paper assembles the - so far available - data-sets regarding PKW models tested in numerous laboratories under free overflow conditions (i.e., no submergence from the tailwater was observed). Both, scientific model investigations to systematically vary the dominant parameters (typically sectional models mounted in a tested in a linear channel) as well as prototype-related physical model investigations (typical full models with a reservoir as upstream condition) are considered. The aim of the paper is to summarize and interpret the geometry of the different PKW models already tested, and to compare these models to existing PKW prototypes, without giving a detailed hydraulic investigation. This comparison might be interesting to compare the outcome of the different investigations, and to find gaps for further research.

\section{EXISTING DATABASES}

\subsection{Prototype $P K W$}

Table 1 lists several built PKWs with their main hydraulic and geometrical characteristics. Data that were not accessible in literature are indicated with N/A.

The use of PKWs as a solution for dam rehabilitation has started in France, at EDF dams (Laugier 2007). Until 2013, five PKWs were built, namely at Goulours Dam, St-Marc Dam, Gloriettes Damand Etroit Dam (Vermeulen et al. 2011), and Malarce Dam. In addition, supplementary PKWs were tested in the frame of model investigations and will presumably be constructed in the next years (namely at Gage II Dam and Raviège Dam). In the EDF projects, the maximum design discharge over the PKWs is $Q=525 \mathrm{~m}^{3} / \mathrm{s}$ (Malarce Dam), which corresponds to a specific discharge $(q=Q / W)$ equal to $12.3 \mathrm{~m}^{2} / \mathrm{s}$.

More recently, several PKWs were built, are under construction or planned in other countries, such as Algeria, Burkina Faso, India, Switzerland and Vietnam. For some cases, the design discharge exceeds $Q=1000 \mathrm{~m}^{3} / \mathrm{s}$, reaching up to $8 ' 700 \mathrm{~m}^{3} / \mathrm{s}$ at Van Pongh Dam. The specific discharges are also considerable, reaching up to $q=40 \mathrm{~m}^{2} / \mathrm{s}$ at of Vinh Son 3 Dam.

PKWs are typically provided to operate under low heads, taking advantage of their overproportional developed crest length. As can be seen in Table 1, most of the PKWs have a ratio $H_{d} / P_{i}$ around 0.3 , where $H_{d}$ is the upstream design head. Some exceptions are the PKWs of 
Sawaa Khuddu Dam (India) and Ouldjet Mellegue Dam (Algeria), where $H_{d} / P_{i}=0.56$ and 0.66 respectively.

Table 1. Main hydraulic and geometrical characteristics of existing and planned PKWs.

\begin{tabular}{|c|c|c|c|c|c|c|c|c|c|c|c|c|}
\hline Project & Country & & $Q_{\mathrm{d}}$ & $q\left(Q_{d} / W\right)$ & $H_{d} / P_{i}$ & $L / W$ & $P_{i} / W_{i}$ & $W_{i} / W_{o}$ & $S_{i}$ & $P_{i} / T_{s}$ & $P_{p x i} / P_{i}$ & Main \\
\hline Hoject & coumtiy & & {$\left[\mathrm{m}^{3} / \mathrm{s}\right]$} & {$[-]$} & {$[-]$} & {$[-]$} & {$[-]$} & {$[-]$} & {$[-]$} & {$[-]$} & {$[-]$} & reference \\
\hline Bambakari & $\begin{array}{l}\text { Burkina } \\
\text { Faso }\end{array}$ & & 1000 & 5.0 & 0.27 & 6.0 & 2.67 & 0.77 & N/A & N/A & 0.0 & $\begin{array}{l}\text { Lemp } \\
\text { et al. }\end{array}$ \\
\hline $\begin{array}{l}\text { Gage II } \\
\text { Dam }\end{array}$ & France & & 400 & 11.8 & 0.25 & 7.8 & 3.75 & 1.23 & 0.67 & 15 & 0.0 & $\begin{array}{l}\text { Dugué et al. } \\
\text { (2011) }\end{array}$ \\
\hline $\begin{array}{l}\text { Raviege } \\
\text { Dam }\end{array}$ & France & B & 400 & 10.4 & 0.32 & 6.8 & 2.08 & 1.50 & 0.51 & 13 & 0.2 & $\begin{array}{l}\text { net } \\
\text { 1) }\end{array}$ \\
\hline Malarce & France & A & 525 & 12.3 & 0.34 & 8.1 & 2.67 & 1.04 & 0.64 & 22 & 0.4 & $\begin{array}{l}\text { Pinc } \\
\text { al. }(2\end{array}$ \\
\hline Goul & France & A & 68 & 7 & 0.31 & 4.9 & 1.15 & 1.80 & 0.53 & 16 & 0.0 & $\begin{array}{l}\text { Ribei- } \\
\text { l. } \\
\text { ) }\end{array}$ \\
\hline St-N & $\mathrm{F}$ & A & 1 & & 32 & 4.3 & 1.35 & 1.41 & 0.48 & 14 & 0.0 & $\begin{array}{l}\text { Leite Ribei- } \\
\text { ro et al. } \\
\text { (2009) }\end{array}$ \\
\hline Etroit & France & A & 82 & 0 & 0.18 & 6.7 & 1.96 & 1.54 & 0.58 & N/A & 0.1 & $\begin{array}{l}\text { Ribei- } \\
\text { l. } \\
\text { ) }\end{array}$ \\
\hline Glo & Fran & A & 90 & 4.9 & 27 & 4.7 & 1.30 & 1.53 & 0.48 & 10 & 0.0 & $\begin{array}{l}\text { Leite Ribei- } \\
\text { ro et al. } \\
\text { (2009) }\end{array}$ \\
\hline Lhasi & India & & 115 & 10 & 0.13 & 6.0 & 2.17 & 1.25 & N/A & N/A & 0.0 & \\
\hline $\begin{array}{l}\text { Van } \\
\text { Pongh } \\
\text { Dam }\end{array}$ & Vietnam & N/A & 8700 & 28.9 & N/A & 5.8 & 2.09 & 1.19 & N/A & 22 & N/A & $\begin{array}{l}\text { Ho Ta } \\
\text { Khanh et al } \\
(2011) \\
\text { Ho Ta }\end{array}$ \\
\hline Dakmi 2 & Vietnam & N/A & 500 & 6.7 & N/A & 5.0 & N/A & N/A & N/A & N/A & 0.0 & $\begin{array}{l}\text { Khanh et al } \\
\text { (2011) }\end{array}$ \\
\hline $\begin{array}{l}\text { Ngan } \\
\text { Truoi }\end{array}$ & Vietnam & N/A & 1560 & 16.3 & N/A & 5.0 & 2.04 & 1.35 & N/A & 16 & N/A & $\begin{array}{l}\text { Ho Ta } \\
\text { Khanh et al } \\
\text { (2011) }\end{array}$ \\
\hline $\begin{array}{c}\text { Vinh Son } \\
3\end{array}$ & Vietnam & N/A & 4000 & 40.0 & N/A & 5.0 & N/A & N/A & N/A & N/A & N/A & $\begin{array}{l}\text { Ho Ta } \\
\text { Khanh et al } \\
\text { (2011) }\end{array}$ \\
\hline $\begin{array}{l}\text { Sawaa } \\
\text { Kuddu }\end{array}$ & India & N/A & 5240 & 38.0 & 0.56 & 4.9 & 1.33 & 1.00 & N/A & N/A & 0.0 & $\begin{array}{l}\text { Das Singhal } \\
\text { and Sharma } \\
\text { (2011) }\end{array}$ \\
\hline $\begin{array}{l}\text { Ouldjet } \\
\text { Mellegue }\end{array}$ & Algeria & & 5240 & 0.7 & 0.66 & 4.8 & N/A & 1.37 & N/A & N/A & N/A & $\begin{array}{l}\text { Pfister et al. } \\
\text { (2012) }\end{array}$ \\
\hline
\end{tabular}

\subsection{Scientific model PKW}

According to present literature, most of the systematic research PKW model studies were conducted in eight laboratories around the world. Table 2 lists the key research projects in the field of experimental PKW investigations. In total, almost 300 PKW model configurations were reported. 
Table 2: Main current players of the PKW investigation.

\begin{tabular}{|c|c|c|c|}
\hline Laboratory & Country & $\begin{array}{l}\text { Number of PKW } \\
\text { models }\end{array}$ & Main references \\
\hline $\begin{array}{l}\text { Laboratory of Hydraulic Developments } \\
\text { and Environment } \\
\text { Briska University }\end{array}$ & Algeria & 83 & $\begin{array}{l}\text { Ouamane and Lempérière } \\
\qquad(2006) \\
\text { Ouamane }(2011)\end{array}$ \\
\hline $\begin{array}{l}\text { Ho Chi Minh City University of Technol- } \\
\text { ogy (HCM) }\end{array}$ & Vietnam & 5 & $\begin{array}{l}\text { Truong Chi Hien et al. } \\
\text { (2006) } \\
\text { HMC Internal reports }\end{array}$ \\
\hline $\begin{array}{l}\text { Water Resources Development \& Man- } \\
\text { agement Department } \\
\text { Indian Institute of Technology Roorkee }\end{array}$ & India & 28 & Das Singhal (2010) \\
\hline $\begin{array}{l}\text { Laboratory of Hydraulic Constructions } \\
\text { Ecole Polytechnique Fédérale de Lausan- } \\
\text { ne (LCH -EPFL) }\end{array}$ & Switzerland & 50 & $\begin{array}{l}\text { Leite Ribeiro et al. (2011) } \\
\text { Leite Ribeiro et al. (2012b) }\end{array}$ \\
\hline $\begin{array}{l}\text { National Hydraulic and Environment La- } \\
\text { boratory } \\
\text { Electricité de France (LNHE - EDF) }\end{array}$ & France & 9 & $\begin{array}{c}\text { De Miranda (2011) } \\
\text { Cicero and Delisle (2013) }\end{array}$ \\
\hline $\begin{array}{l}\text { Utah Water Research Laboratory } \\
\text { Utah State University }\end{array}$ & USA & 13 & Anderson (2011) \\
\hline $\begin{array}{l}\text { Hydraulics in environmental and civil en- } \\
\text { gineering } \\
\text { Liège University (HECE - ULG) }\end{array}$ & Belgium & 52 & Machiels (2012) \\
\hline $\begin{array}{l}\text { Department of Civil Engineering } \\
\text { Isfahan University of Technology }\end{array}$ & Iran & 33 & $\begin{array}{l}\text { Kabiri-Samani and Javaheri } \\
\text { (2012) }\end{array}$ \\
\hline
\end{tabular}

\section{OVERVIEW AND COMPARISON}

Table 3 gives an overview of the tested range of six dimensionless geometric parameters of so far tested PKWs, including all listed investigations, i.e., prototype PKWs as well as scientific models (being the sum of Tables 1 and 2). It can be seen that - with the exception of $P_{p x i} / P_{i}$, all prototypes values were also studied in the scientific models. Or, in other words, the scientific investigations include larger limits than so far applied on prototypes.

Table 3: Limits of dimensionless geometrical ratios, comparison of scientific models with prototype PKWs.

\begin{tabular}{clcccccc}
\hline & $L / W$ & $W_{i} / W_{o}$ & $P_{i} / W_{i}$ & $P_{i} / T_{s}$ & $S_{i}$ & $P_{p x i} / P_{i}$ \\
\hline \multirow{2}{*}{$\begin{array}{c}\text { Scientific } \\
\text { model }\end{array}$} & Maximum & 8.5 & 2.45 & 4.71 & 300 & 2.00 & 0.43 \\
& Minimum & 2.5 & 0.00 & 0.59 & 5 & 0.25 & 0.00 \\
\hline \multirow{2}{*}{ Prototype } & Maximum & 8.1 & 1.80 & 3.75 & 22 & 0.67 & 0.38 \\
& Minimum & 4.3 & 0.77 & 1.15 & 10 & 0.48 & 0.00 \\
\hline
\end{tabular}

The dominant dimensionless parameters influencing the discharge capacity of PKWs are the ratios $L / W$ and $H_{d} / P_{i}$. For the experiments performed at EPFL (Leite Ribeiro et al. 2012c), exclusively these two terms are sufficient to predict the rating curve of all tested PKWs under all discharges with a maximum error of only $\pm 17 \%$. Herein, in order to focalize on the geometric parameters of the PKWs, the parameter $H_{d} / P_{i}$ is not further considered. However, most of the scientific models include a test range of $0.1<H_{d} / P_{i}<3.0$, largely exceeding that of the prototypes (Table 1).

Hereafter, some dimensionless geometrical ratios of the numerous studies are visually compared. 
Figure 2 plots $P_{i} / W_{i}$ versus $L / W$ for both, prototype and the scientific models. Generally, $P_{i} / W_{i}$ increases in parallel with augmenting ratios $L / W$. This is explained with the fact that, for a given total PKW width $W$, an increase of the ratio $L / W$ is typically linked to increasing the number of cycles and consequently decreasing the width of the inlet key $W_{i}$.

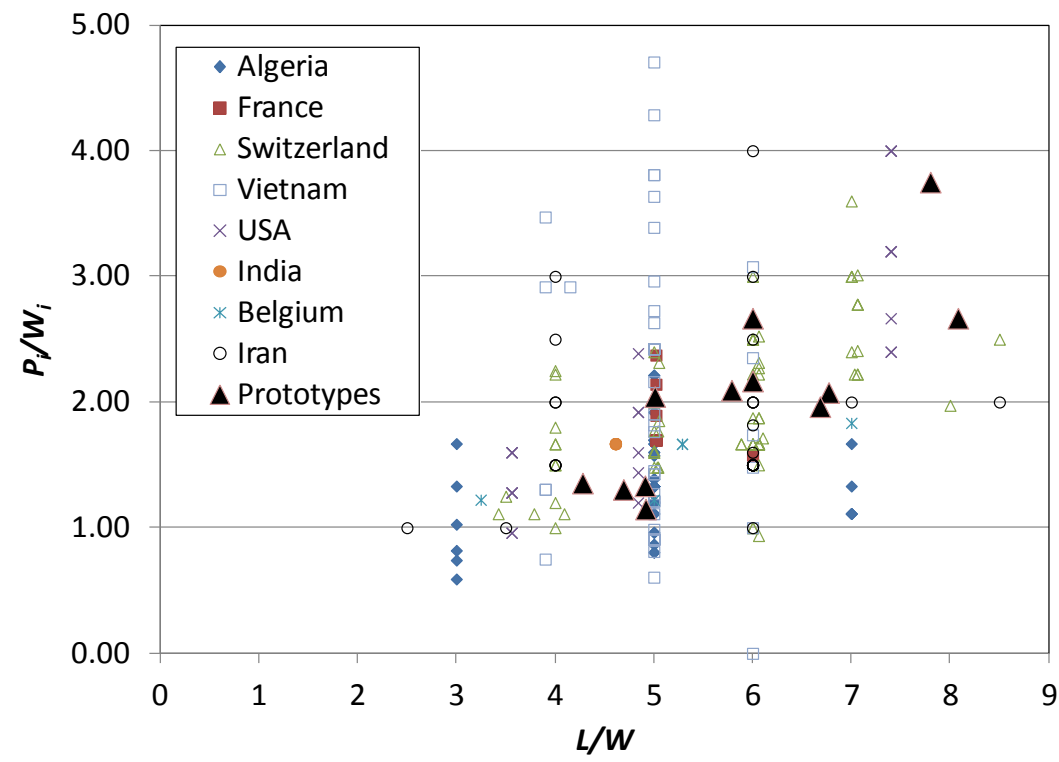

Figure 2. $P_{i} / W_{i}$ as a function of $L / W$ for all herein listed PKWs (Tables 1 and 2).

Another possibility to increase the ratio $L / W$ is the augmentation of the streamwise PKW length $B$ (particularly $B_{i}$ and $B_{o}$ ). However, this impacts the slope $S_{i}$ of the keys. According to Figure 3, this option was rarely exhausted, as most tests range around slopes of $S_{i}=0.5$ to almost $1.0 \mathrm{~m} / \mathrm{m}$.

Concerning the scientific model tests, the major part of them was conducted with slopes between $S_{i}=0.3$ and $1.0 \mathrm{~m} / \mathrm{m}$. Leite Ribeiro et al. (2011) have suggested that the influence of the slopes disappears when the upstream hydraulic head $H_{d}$ is normalized with the height of the inlet key $P_{i}$ for a range of slopes between 0.3 and 0.8. Results presented by Machiels (2012) and Machiels et al. (2011) mention an upper limit in around $S_{i}=0.75$.

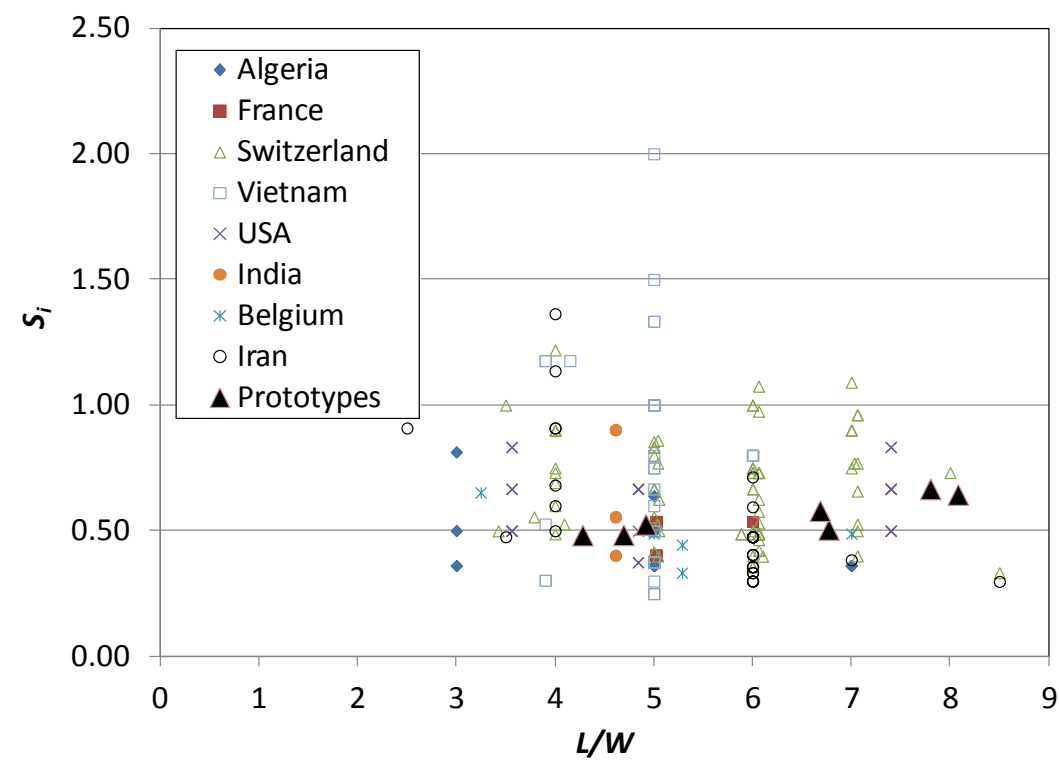

Figure 3. $S_{i}$ as a function of $L / W$ for all herein listed PKWs (Tables 1 and 2). 
Although the ratio between the inlet and outlet key widths $W_{i} / W_{o}$ is associated to the discharge efficiency of a PKW, its influence has been considered as secondary (Leite Ribeiro et al. 2012c). The scientific model tests varied this ration in large ranges to find optimal configurations (roughly between $2.5<W_{i} / W_{o}<0.5$ ), with a typical optimal value around $W_{i} / W_{o}=1.5$ (Leite Ribeiro 2012c, Machiels et al. 2010, Ouamane and Lempérière 2006).

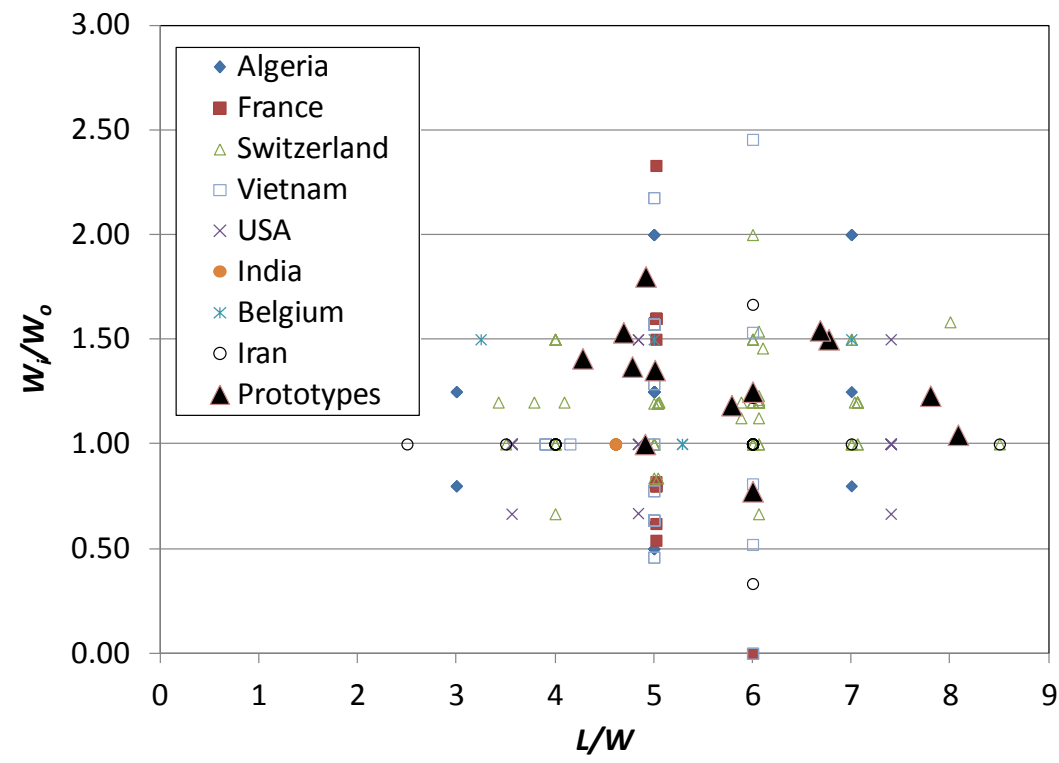

Figure 4. $W_{i} / W_{o}$ as a function of $L / W$ for all herein listed PKWs (Tables 1 and 2).

According to a 3D numerical study performed by Laugier et al. (2011), the thickness of the side walls has an important impact on the PKW discharge capacity (up to 20\%), especially for low heads. For the existing PKW prototypes, the vertical walls of each key are made of reinforced concrete, with thickness between 0.2 and $0.3 \mathrm{~m}$. Considering the height of the walls $\left(P_{i}\right)$ as reference, it leads to ratios $P_{i} / T_{s}$ between 10 and 22 for the existing PKWs. As shown in Figure 5, most of the scientific model tests were performed with $P_{i} / T_{s}$ is in the range of those considered in the prototypes. As suggested by Laugier et al. (2011), the PKW discharge capacity may be increased by reducing the thickness of the walls and consequently increasing the ratio $P_{i} / T_{s}$. Such configurations were tested in Algeria and Iran.

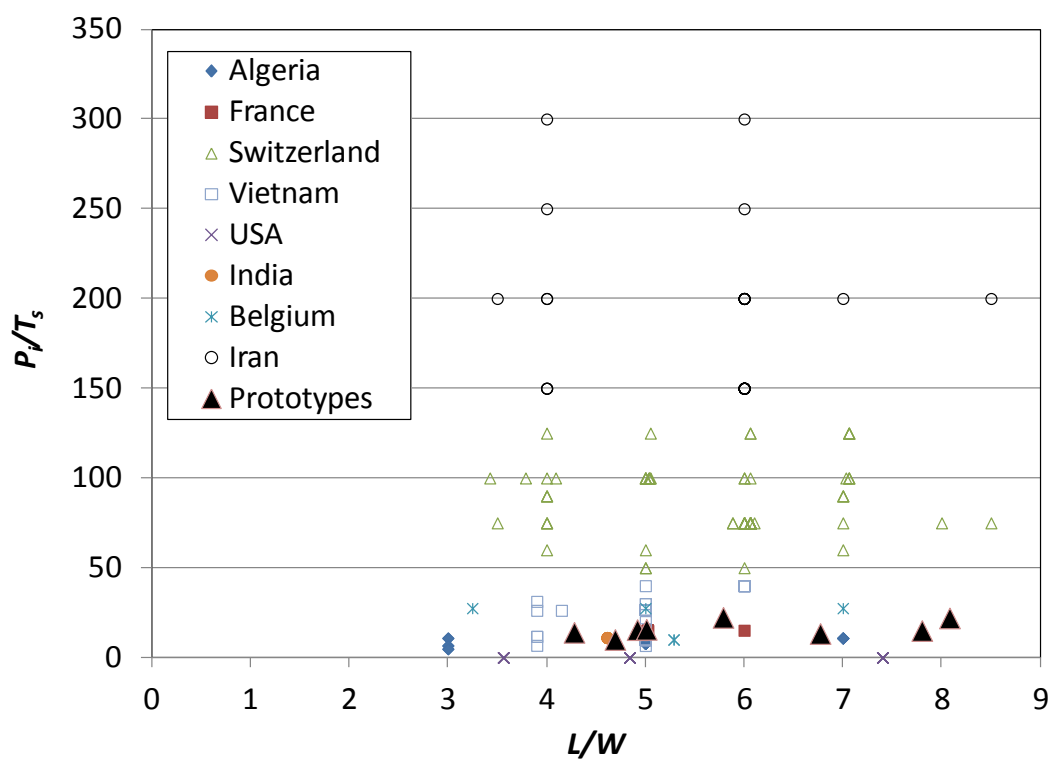

Figure 5. $P_{i} / T_{s}$ as a function of $P_{i} / W_{i}$ for all herein listed PKWs (Tables 1 and 2). 
Until today, parapet walls were studied in three PKWs of EDF, namely at Etroit and Malarce Dams (built in both inlet and outlet keys) and in Raviège Dam (studied in both inlet and outlet keys and also in the outlet keys only). According to the results of Leite Ribeiro et al. (2012b) and Machiels et al. (online), the use of the parapet walls in the inlet key acts as an increase of the PKW height $P_{i}$. Therefore, the differences between the scientific tests performed in Switzerland, USA and Belgium and the two prototype models shown in Figure 6 are not important in terms of representativeness of the tests. However, as demonstrated by Leite Ribeiro et al. (2012b), parapet walls are efficient if applied in the outlet key.

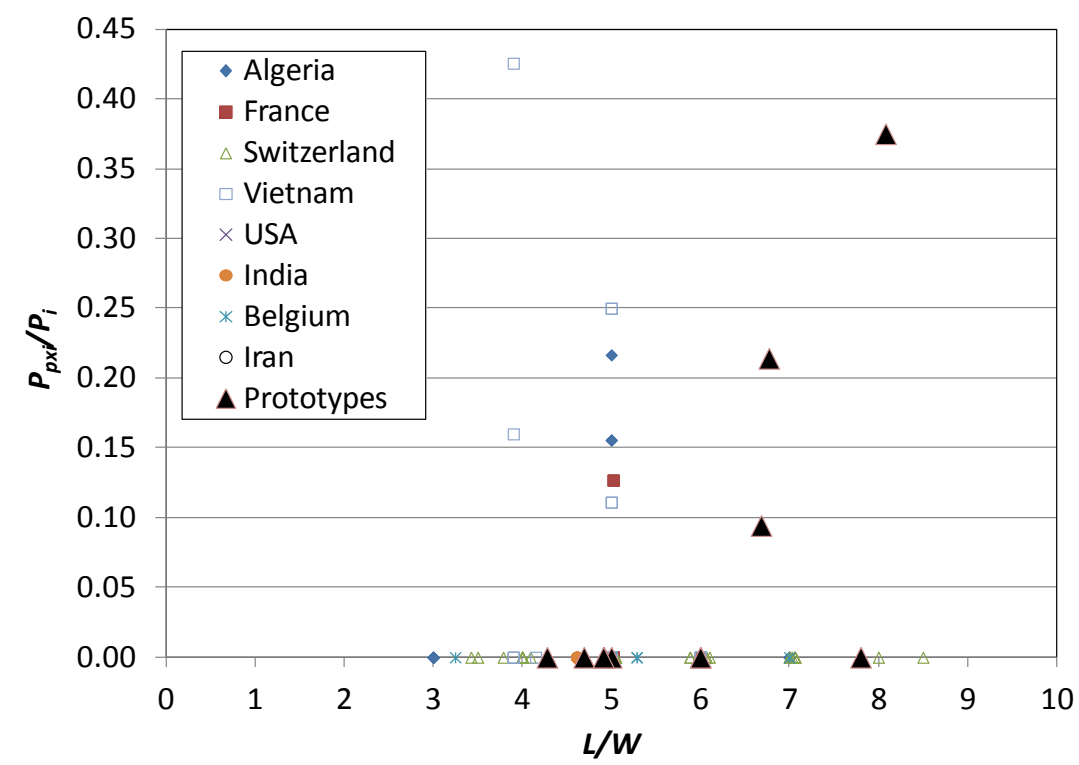

Figure 6. $P_{p x i} / P_{i}$ as a function of $L / W$ for all herein listed PKWs (Tables 1 and 2).

\section{CONCLUSIONS}

The present paper gives a rough overview on so far performed model tests related to PKW, including investigations related to specific prototypes as well as research models to conduct systemic parameter analyses.

The main outcomes are:

$>\quad$ The application of PKW as an alternative for dam rehabilitation and new spillway project increased during the last years. In parallel, an important database of systematic laboratory tests was created.

$>\quad$ The key parameters controlling the PKW discharge capacity are $L, W, P_{i}$ and $H$. These have already been studied in detail by different authors based on systematic tests performed in laboratory channels.

$>\quad$ The studies in the next years regarding PKWs operating under free flow conditions will probably concentrate on the analysis of the influence of the secondary parameters, such as the approach conditions, the shape and the thickness of the crest, the shape of the deflectors below the outlet keys, the length of the overhangs, and the presence of parapets walls in the outlet key.

Nevertheless, one has to notice that the efficiency of PKWs in terms of their rating curve may be optimized thereby maximally by few percent. As compared to the uncertainty related to the derivation of the design flood, such an optimization process is to question. 


\section{ACKNOWLEDGEMENTS}

The authors kindly thank Mr. Guy-Michel Cicero, EDF, France; Prof. Dr. Blake Tullis, Utah State University, USA; Prof. Ahmed Ouamane, University of Briska, Algeria; Mr. Ho Ta Khanh, EDF, France; Prof. Abdorreza Kabiri-Samani and Mr. Amir Javaheri, Isfahan University of Technology, Iran, for providing key limits of their model investigations.

\section{REFERENCES}

Anderson, R. M. 2011. Piano Key Weir Head Discharge Relationships. MSc Thesis. Paper 880. http://digitalcommons.usu.edu/etd/880

Anderson, R.M., Tullis, B.P. 2011. Influence of Piano Key Weir geometry on discharge. Proc. Intl Workshop on Labyrinths and Piano Key Weirs PKW 2011, CRC Press, 75-80.

Anderson, R.M., Tullis, B.P. 2012. Comparison of Piano Key and Rectangular Labyrinth Weir Hydraulics. Journal of Hydraulic Engineering 138(4): 358-361.

Blancher, B., Montarros, F., Laugier, F. 2011. Hydraulic comparison between Piano Key Weirs and labyrinth weirs. Proc. Intl Workshop on Labyrinths and Piano Key Weirs PKW 2011, CRC Press, 141-150.

Chi Hien, T., Thanh Son, H., Ho Ta Khanh, M. 2006. Results of some 'piano keys' weir hydraulic model tests in Vietnam. Proc. $22^{\text {nd }}$ Intl Congress of Large Dams, Q87, R39, Vol. IV, ICOLD, Barcelona, Spain, 581-595.

Cicero, G.M., Delisle, J.R. 2013. Effects of the crest shape on the discharge efficiency of a Type A PKW. This issue.

Da Singhal, G., Sharma, N. 2011. Rehabilitation of Sawara Kuddu Hydroelectric Project - Model studies of Piano Key Weir in India. Proc. Intl Workshop on Labyrinths and Piano Key Weirs PKW 2011, CRC Press, 241-250.

De Miranda, D.A. 2011. Etude expérimentale sur modèle réduit de la débitance des seuils PK weir. MSc Thesis, Laboratoire de constructions hydrauliques (LCH/EPFL), Switzerland, and Laboratoire d'Hydraulique St-Venant (EDF), France. June 2011. In French

Dugué, V., Hachem, F., Boillat, J-L., Nagel, V. Roca, J-P., Laugier, F. 2011. PK Weir and flap gate spillway for the Gage II Dam. Proc. Intl Workshop on Labyrinths and Piano Key Weirs PKW 2011, CRC Press, 35-42.

Erpicum, S., Nagel, V., Laugier, F. 2011. Piano Key Weir design of Raviege dam. Proc. Intl Workshop on Labyrinths and Piano Key Weirs PKW 2011, CRC Press, 43-50

Ho Ta Khanh, M., Sy Quat, D., Xuan Thuy, D. 2011a. P.K. weirs under design and construction in Vietnam. Proc. Intl Workshop on Labyrinths and Piano Key Weirs PKW 2011, CRC Press, 225-232.

Ho Ta Khanh, M., Chi Hien, T., Thanh Hai, N. 2011b. Main results of the P.K. weir model tests in Vietnam (2004 to 2010). Proc. Intl Workshop on Labyrinths and Piano Key Weirs PKW 2011, CRC Press, 191-198.

Kabiri-Samani, A., Javaheri, A. 2012. Discharge coefficient for free and submerged flow over Piano Key Weirs. In Journal of Hydraulic Research 50(1): 114-120.

Laugier, F. 2007. Design and construction of the first Piano Key Weir (PKW) spillway at the Goulours dam. Hydropower \& Dams 13(5): 94-100.

Laugier, F., Lochu, A., Gille, C., Leite Ribeiro, M. Boillat, J-L. 2009. Design and construction a labyrinth PKW spillway at St-Marc dam, France. Hydropower \& Dams 15(5): 100-107.

Laugier, F., Pralong, J., Blancher, B. 2011. Influence of structural thickness of sidewalls on PKW spillway discharge capacity. Proc. Intl Workshop on Labyrinths and Piano Key Weirs PKW 2011, CRC Press, 159-165

Leite Ribeiro, M., Bieri, M., Boillat, J-L., Schleiss, A., Delorme, F., Laugier, F. 2009. Hydraulic capacity improvement of existing spillways - Design of piano key weirs. $23^{\text {rd }}$ Congress of Large Dams Q90, R43, 25-29. Brasilia, Brazil.

Leite Ribeiro, M., Bieri, M., Boillat, J. L., Schleiss, A.J., Singhal, G., Sharma, N. 2012a. Discharge capacity of Piano Key Weirs. Journal of Hydraulic Engineering 138(2): 199-203.

Leite Ribeiro, M., Boillat, J.-L., Schleiss, A. J. 2011. Experimental parametric study for hydraulic design of PKWs. Proc. Intl Workshop on Labyrinths and Piano Key Weirs PKW 2011, CRC Press, 183-190

Leite Ribeiro, M., Boillat, J.-L., Schleiss, A., Laugier, F., Albalat, C. 2007. Rehabilitation of St-Marc Dam - Experimental Optimization of a Piano Key Weir. Proc. $32^{\text {nd }}$ Congress IAHR, Venice, Italy.

Leite Ribeiro, M., Pfister, M., Boillat, J-L., Schleiss, A.J., Laugier, F. 2012b. Piano Key Weirs as efficient spillway structure. $24^{\text {th }}$ Congress of Large Dams Q94 R2, Kyoto, Japan.

Leite Ribero, M., Pfister, M., Schleiss, A.J., Boillat, J.L. 2012c. Hydraulic design of A-type Piano Key Weirs. Journal of Hydraulic Research 50(4): 400-408.

Lempérière, F., Ouamane, A. 2003. The Piano Keys weir: a new cost-effective solution for spillways. $H y$ dropower \& Dams 9(5), 144-149. 
Lempérière, F., Vigny, J.P., Ouamane, A. 2011. General comments on Piano Kew Weirs: The past and present. Proc. Intl Workshop on Labyrinths and Piano Key Weirs PKW 2011, CRC Press, 17-25.

Machiels, O. 2012. Experimental study of the hydraulic behaviour of Piano Key Weirs, PhD Thesis, Faculty of applied science, University of Liège, Belgium.

Machiels, O., Erpicum, S., Archambeau, P., Dewals, B., Pirotton, M. 2010. Analyse expérimentale de l'influence des largeurs d'alvéoles sur la débitance des déversoirs en touches de piano. La Houille Blanche (2), 22-28.

Machiels, O., Erpicum, S., Archambeau, P., Dewals, B., Pirotton, M. 2011a. Influence of Piano Key Weir height on its discharge capacity. Proc. Intl Workshop on Labyrinths and Piano Key Weirs PKW 2011, CRC Press, 59-66

Machiels, O., Erpicum, S., Dewals, B., Archambeau, P. Pirotton, M. 2011b. Experimental observation of flow characteristics over a Piano Key Weir, Journal of Hydraulic Research 49(3): 359-366.

Machiels, O., Erpicum, S., Archambeau, P., Dewals, B., Pirotton, M. (online). Parapet wall effect on Piano Key Weirs efficiency. Journal of Irrigation and Drainage Engineering doi:10.1061/(ASCE)IR.1943-4774.0000566.

Ouamane, A. 2011. Nine years of study of the Piano Key Weir in the university laboratory of Biskra. Proc. Intl Workshop on Labyrinths and Piano Key Weirs PKW 2011, CRC Press, 51-58.

Ouamane, A., Lempérière, F. 2006. Design of a new economic shape of weir. Proc. Intl Symposium on Dams in the Societies of the $21^{\text {st }}$ Century, Barcelona, Spain, 463-470.

Pfister, M., Erpicum, S., Machiels, O. Schleiss, A.J., Pirotton, M. 2012. Discussion Discharge coefficient for free and submerged flow over Piano Key weirs, Journal of Hydraulic Research 50(6), 642-643

Pfister, M., Capobianco, D., Tullis, B., Schleiss, A.J. 2013. Debris blocking sensitivity of Piano Key weirs under reservoir type approach flow. Journal of Hydraulic Engineering [in press]

Pinchard, T, Boutet, J.-M., Cicero, G.M. 2011. Spillway capacity upgrade at Malarce dam: Design of an additional Piano Key Weir spillway. Proc. Intl Workshop on Labyrinths and Piano Key Weirs PKW 2011, CRC Press, 233-240

Pralong, J., Vermeulen, J., Blancher, B., Laugier, F., Erpicum, S., Machiels, O., Pirotton, M., Boillat, J.L., Leite Ribeiro, M., Schleiss, A.J. 2011. A naming convention for the Piano Key Weirs geometrical parameters. Proc. Intl Workshop on Labyrinths and Piano Key Weirs PKW 2011, CRC Press, 271-278.

Vermeulen, J., Laugier, F., Faramond, L., Gilles, C. 2011. Lessons learnt from design and construction of EDF first Piano Key Weirs. Proc. Intl Workshop on Labyrinths and Piano Key Weirs PKW 2011, CRC Press, 215-224. 